\title{
The Doctrine of Capital Maintenance and its Statutory Developments: An Analysis
}

\author{
Md. Saidul Islam*
}

\begin{abstract}
This article emphasizes on the implication of the doctrine of capital maintenance which means the capital of a company needs to be kept intact for there is a contribution of the creditors and retaining the capital is normally expected to guarantee repayment to the creditors. Any reduction of capital can diminish the liability of members and consequently the position of the creditors can be vulnerable. Therefore, an attempt has been made by this study to reveal the origin, objective and application of the doctrine of capital maintenance to find out a way by which we can save the interest of the creditors as well as satisfy the needs of the modern business.
\end{abstract}

\section{Methodology}

Analytical method of research has been followed for this study.

\section{Introduction}

The doctrine of capital maintenance - i.e. that a company must obtain proper consideration for shares that it issues and that having received such capital it must not repay it to members except in certain circumstances - is a fundamental principle of company law. ${ }^{1}$ In fact, the doctrine emphasizes on a fundamental duty of the companies to keep the capital intact for the safety of the creditors giving the mandate to the courts to supervise whether the capital is dissipated lawfully or not.

The doctrine of maintenance of capital underpins the legal rules in the following important areas': payment of dividends or other distributions to shareholders; reduction of a company's share capital and/or reserves; prohibition on the provision by a company of financial assistance for the purchase of its own shares; and a company's redemption or purchase of its own shares.

\section{Basics of the Doctrine of Capital Maintenance}

Due to the limited liability of shareholders, protection of creditors has always been a concern. To that end there developed the doctrine of capital maintenance which essentially is a collection of rules designed to ensure, firstly, that a company obtains

\footnotetext{
* Assistant Professor, Department of Law, Eastern University

${ }^{1}$ Please visit http://www.nortonrosefulbright.com/knowledge/publications/17080/capital-maintenancethe-companies-act-2006 accessed on 08/12/13.

2 Please visit http://www.nortonrosefulbright.com/knowledge/publications/17080/capital-maintenancethe-companies-act-2006 accessed on 08/12/13.
} 
the capital which it has purported to raise, and secondly, that the capital is maintained, subject to the exigencies of the business, for the benefit and protection of the creditors of the company. Thus, the objective of the doctrine of capital maintenance is to prevent fraudulence and to the creditors in companies by reducing share capital and to ensure liabilities of shareholders. Therefore, an attempt must be made to compromise the interest of creditors in the complete satisfaction of their claims and the interest of corporations in managerial freedom.

It is a fundamental principle of company law that the share capital must be maintained. It has been said that "a company cannot, without the leave of the court or the adoption of a special procedure, return its capital to its shareholders. It follows that a transaction which amounts to an unauthorized return of capital is ultra vires and cannot be validated by shareholder ratification or approval." ${ }^{3}$

The principle that the share capital of a company must be maintained boils down to the rules that paid up share capital must not be returned to its members and their liability in respect of capital not paid up on shares must not be reduced. ${ }^{4}$

The doctrine has the following general consequences ${ }^{5}$ subject to exceptions approved by the national legislations: 1) a company generally cannot purchase its own shares unless it follows the strict procedures laid down by the Act; 2) a subsidiary company generally must not be a member of its holding company; 3 ) it is generally unlawful for a company to give any kind of financial assistance for the acquisition by any person of its own shares or those of its holding company; 4) dividends must not be paid to the shareholders except out of the distributable profits; 5) where a public company suffers a serious loss of capital, a meeting of the company can be called to discuss the issue.

There are certain exceptions to the principle: i) if the law permits, a company may reduce its share capital with the consent of the court; ii) a company may redeem its shares if the Act concerned allows it; iii) a company may purchase its own shares under a procedure prescribed by the law; iv) capital may be returned to the members, after the debts of the company have been paid in a winding up. ${ }^{6}$

Capital maintenance, in another view, is stating that a profit should not be recognized unless a business has at least maintained the amount of its net assets (i.e., capital)

\footnotetext{
${ }^{3}$ Hoffman J. in Aveling Barford Ltd. V. Perion Ltd. (1989) 1 W. L. R. 360 at p. 364.

${ }_{5}^{4}$ Geoffrey Morse, Charlesworth and Morse: Company Law, Fourteenth Edition, 1991, ELBS, p. 190.

${ }^{5}$ Ibid, pp. 190-191.

${ }^{6}$ Ibid.
} 
during an accounting period. Stated differently, this means that profit is essentially the increase in net assets during a period. ${ }^{7}$

Capital maintenance, in accounting, involves two sub-concepts ${ }^{8}:$ the financial and the physical capital. The financial capital maintenance concept is that the capital of a company is only maintained if the financial or monetary amount of its net assets at the end of a financial period is equal to or exceeds the financial or monetary amount of its net assets at the beginning of the period, excluding any distributions to, or contributions from, the owners. On the other hand, the physical capital maintenance concept is that the physical capital is only maintained if the physical productive or operating capacity, or the funds or resources required to achieve this capacity, is equal to or exceeds the physical productive capacity at the beginning of the period, after excluding any distributions to, or contributions from, owners during the financial period. However, this article only involves the study on the financial capital maintenance

\section{Origin and Rationale of the Doctrine of Capital Maintenance}

The reasons for the origin of the doctrine can be twofold; firstly to protect the interest of the creditors, and secondly to ensure the lawful dissipation of the assets of the company. The courts have always been anxious to keep the capital of the company intact ${ }^{9}$ for "the creditor gives credit to that capital; gives credit to the company on the faith of the representation that the capital shall be applied only for the purpose of the business and, therefore, has a right to say that the corporation shall keep its capital and not return it to its shareholders." 10

However, it is worth mentioning that the doctrine has been developed through a series of judicial interpretation in company law cases in England. Jessel M. R., in Flitcrofts Case $^{11}$, indirectly stated about two aspects of the doctrine of capital maintenance-“ i) the creditors have a right to see that the capital is not dissipated unlawfully; and ii) the members must not have the capital returned to them surreptitiously. These two aspects are governed by the rules of a) capital reduction and b) company distributions."

In Trevor v Whitworth, ${ }^{12}$ a company bought back almost a quarter of its own shares. During liquidation of the company, one shareholder applied to court for the balance

\footnotetext{
${ }^{7}$ Available on http://www.accountingtools.com/ questions-and-answers/ what- is- capital maintenance. html, accessed on 08/12/13.

8 Available on http://www.oxfordreference.com/view/10.1093/oi/authority.20110803095547696, see also http://www.wisegeek.com/what-is-capital-maintenance.htm, accessed on 08/12/13.

${ }^{9}$ Dr. M. Zahir, Company and Securities Laws, First published in 2000, the University Press Limited, Dhaka, p. 50.

${ }^{10}$ Jessel M. R. in Flitcrofts Case (1882) 21 Ch. D. 519.

${ }^{11}$ Ibid; (1882) 21 Ch. D. 519.

12 (1887) 12 App. Cas. 409.
} 
of amounts owed to him after the buyback. The Court of Appeal held that he should be paid. The House of Lords held the buyback was ultra vires the company declaring that the company could not purchase its own shares, even though there was a provision to that effect in the memorandum of association since this would result in a reduction of capital. It is also held that there can be no return of capital to the members other than on a proper reduction of capital duly sanctioned by the court. In Aveling Barford Ltd. V. Perion Ltd., ${ }^{13}$ it is held that "on a winding up of company, shareholders can retrieve their capital only if all the creditors have been paid."

The principle was authoritatively stated by the House of Lords in Trevor $v$ Whitworth, and has been subsequently applied both by the courts and in statutory provisions. The objective of the rule has always been thought to be the protection of creditors, who are entitled to assume that the risk of a loss of the company's capital is confined to ordinary commercial activity. The rule is firmly entrenched in both English and Indian law, although its scope varies considerably.

These case laws have been the foundations of the doctrine of capital maintenance. But the position of the UK has been modified into a relaxed one due to the necessities of the modern business demands in various facets. In the UK, the rule governing the doctrine of capital maintenance was reformed in 1980 and replaced with a statutory procedure so that shares can either be classed as redeemable or be bought back, under the Companies Act 2006 sections 684-723. In Australia, share buybacks are allowed under sections 257A-257J of the Corporations Act 2001. The doctrine remains to be the foundation stone of the company laws in countries. But, modern business needs have persuaded the countries to relax some of the aspects of the doctrine.

\section{Contemporary Statutory Laws Governing the Doctrine of Capital Maintenance}

This section of the study shows how the doctrine of capital maintenance is being governed in countries having the similar features and approaches of laws of companies especially on capital management.

\subsection{In Bangladesh}

The traditional restrictive approach has been taken in respect of governing the rules of capital maintenance in the Companies Act, 1994 in Bangladesh.

\section{a. Reduction of Capital}

No company limited by shares shall have power to buy its own shares or the shares of a public company of which it is a subsidiary company, unless the consequent

${ }^{13}$ (1989) BCLC 626 at p. 630-3. 
reduction of capital is effected and sanctioned in the manner provided by sections 59 to $70 .{ }^{14}$

Where the proposed reduction of share capital involves either diminution of liability in respect of unpaid share capital or the payment to any shareholder of any paid-up share capital, every creditor shall be entitled to bring objection to the court against that reduction. ${ }^{15}$ The Court if satisfied with respect to every creditor of the company who under this Act is entitled to object to the reduction, that either consent to the reduction has been obtained or his debt or claim has been discharged or has been determined or has been secured may make an order confirming the reduction on such terms and conditions as it thinks fit. ${ }^{16}$

\section{b. Financial Assistance}

No company limited by shares other than private company or a subsidiary company of a public company, shall give whether directly or indirectly, and whether by means of a loan guarantee the provision of security or otherwise any financial assistance for the purpose of or in connection with a purchase made or to be made by any person of any shares in the company: Provided that nothing in this section shall, where the lending of money is part of the ordinary business of a company, be taken to prohibit the lending of money by the company in the ordinary course of its business. ${ }^{17}$

\section{c. Dividends}

No dividend shall be paid otherwise than out of profits of the year or any other undistributed profits. ${ }^{18}$

\section{d. Purchase of own share}

A company limited by shares is not generally entitled to buy its own shares unless they follow the proper procedure of it prescribed under the provisions of the Companies Act, 1994. However, a company can buy its own shares out of its profit capital as per the Companies Act, 1994.

\subsection{In England ${ }^{19}$}

In England, the Companies Act 2006, hereinafter called as CA 2006, makes a number of important changes to the rules relating to capital maintenance and, in line with the deregulatory objectives of the Act, a number of the statutory requirements in this regard have been relaxed. This briefing discusses some of the key areas of law which

\footnotetext{
${ }^{14}$ Section 58 (1) of the Companies Act, 1994.

${ }^{15}$ Section 62 of the Companies Act, 1994.

${ }^{16}$ Section 64 of the Companies Act, 1994.

${ }^{17}$ Section 58 (2) of the Companies Act, 1994.

${ }_{18}$ Article 98, Schedule-I of the Companies Act, 1994.

19 Please visit http://www.nortonrosefulbright.com/knowledge/publications/17080/capitalmaintenance-the-companies-act-2006 accessed on 08/12/13.
} 
have developed in relation to capital maintenance and explains the recent deregulatory measures which have been introduced.

The general principles governing the doctrine of capital maintenance were originally developed by the courts and since then have been increasingly superseded by statute, most notably Part V of the Companies Act 1985 (hereinafter mentioned as CA 1985) and, from the applicable dates of implementation, Parts 17, 18 and 23 of the Companies Act 2006. In particular, with effect from 1 October 2008, the rules on unlawful financial assistance will no longer apply to private companies (in most circumstances) and private companies will also be allowed to reduce their share capital without the need to go to court.

\section{a. Distributions}

The provisions relating to distributions in the CA 1985 have broadly been restated in Part 23 CA 2006 which came into force on 6 April 2008 and applies to distributions made on or after that date. It continues to be the case that a dividend or distribution to members cannot be made except out of profits available for the purpose by reference to "relevant accounts" and Part 23 sets out the rules relating to permissible distributions.

\section{b. Reduction of Share Capital}

From 1 October 2008, the CA 2006 introduces a new procedure for private companies to be able to reduce their share capital by a special resolution supported by a solvency statement given by all the directors. This new procedure does not require court approval of the reduction and introduces ability for the private company concerned to reduce its capital in any way which was previously only possible if the company was an unlimited company.

It will not be permissible to qualify a solvency statement in any way and directors will commit a criminal offence if they make a solvency statement without having reasonable grounds for the opinions expressed in it. The nature and extent of the work which will have to be done to ensure that directors have reasonable grounds for giving a solvency statement will depend on the circumstances.

In relation to reductions of capital confirmed by the court, the CA 2006 broadly restates the procedure contained in the CA 1985, subject to certain minor amendments which come into effect on 1 October 2009. The court-approved route is available to both public and private companies, unlike the new out of court procedure referred to above which only applies to private companies.

\section{c. Financial Assistance}

The prohibition on the giving of financial assistance by private companies in most circumstances will be repealed with effect from 1 October 2008. As a result of this 
repeal, from 1 October 2008, there will no longer be any statutory whitewash procedure. However, the prohibition on the giving of financial assistance by public companies contained in the CA 1985 will be retained until 1 October 2009, when it will be replaced by similar provisions in Chapter 2 of Part 18 CA 2006. In addition, a private company will continue to be unable to give financial assistance for the acquisition of shares in its (direct or indirect) public holding company.

Notwithstanding the repeal of the statutory rules, a transaction which might once have constituted unlawful financial assistance still needs to be considered in the light of the following general company law principles which must continue to be taken into account: the transaction must be in the best interests of the company ("likely to promote the success of the company for the benefit of its members" in accordance with section 172 of the CA 2006); and the transaction must not breach the rules on distributions or otherwise constitute an illegal reduction in the capital of the company.

\section{d. Purchase of Own Shares}

The general rule is that a limited company may not acquire its own shares by purchase, subscription or otherwise, except as permitted. Part 18 CA 2006, which comes into effect on 1 October 2009, brings together the current methods by which a limited company can acquire its own shares and section 658 CA 2006 prohibits the acquisition by a limited company of its own shares except in accordance with the provisions of that Part. One advantage of a company reducing its share capital by purchasing its own shares is that the purchase price for the shares concerned may exceed the amount of capital that those shares represent.

The key changes to the capital maintenance rules introduced by the CA 2006, being the repeal of the statutory prohibition on the giving of financial assistance by private companies and the new out of court reduction of capital procedure for private companies, are to be welcomed. Whilst it will be interesting to see how market practice develops in relation to the new out of court reduction procedure available to private companies, the changes should simplify many transactions, shorten transaction timetables and reduce costs.

\subsection{In Singapore ${ }^{20}$}

The Companies (Amendment) Act 2005 has reformed the law of Singapore on capital maintenance substantially. It has, inter alia, enabled a company that satisfies the requisite solvency tests to reduce capital, engage in financial assistance and share buyback. It is argued that whilst the reforms have reduced compliance costs, the failure to bring the solvency-based reforms to their logical conclusion has made Singapore law's on capital maintenance incoherent.

${ }^{20}$ Wee Meng Seng, "Reforming Capital Maintenance Law: The Companies (Amendment) Act 2005", Singapore Academy of Law, (2007) 19 SAcLJ Part II (September), Summary. 


\subsection{In India}

The Indian Companies Act, 1956, hereinafter mentioned as 'the Act', contains an ample number of provisions restricting a company to deal freely with the capital of it. The Act deals vehemently with the doctrine of capital maintenance. It has been observed that when a company purchases back its shares then it will amount to reduction of capital. To prevent this capital reduction section 77AA has been enacted which says that when a company purchases its own shares out of free reserves, then a sum equal to the nominal value of the shares so purchased shall be transferred to the capital redemption reserve account and details of such transfer shall be disclosed in the balance sheet. ${ }^{21}$

A limited company is also authorized to issue preference shares and whenever these shares are redeemed it amounts to reduction of capital, but section 80 of the Act says that the redemption of preference shares should only be made out of the profits of the company available for the distribution as dividend or from the fresh issue of capital. If the preference shares are redeemed from any other source the company must build up a capital redemption reserve under proviso (d) to section 80 (1) of the Act. This provision is there to support the fundamental principle that the capital of the company must be maintained. ${ }^{22}$

Further it is very much explicit that if a company fails to make profit but to maintain goodwill decides to distribute dividend, it will certainly reduce its share capital. Section 205 of the Act lays down the prohibition on such distribution as it says that a dividend (including interim dividend) can be paid out of current profits or profits accumulated of earlier years. Amount of depreciation also has to be calculated and for this purpose the Board meets to decide how much amount need to be transferred to the reserves as per the Act. ${ }^{23}$ Through this manner capital in the reserve account is always maintained and the company is not allowed to touch this capital. Hence it helps in the protection of the creditors.

But the Act also provides some provisions which show a departure from the above stringent guidelines. As per the sections 100-105 of the Act a company is allowed to reduce its share capital depending upon the special resolution and the court's order.

\subsection{In the United States ${ }^{24}$}

In the United States there is no general rule prohibiting limited companies from buying shelf owned shares. An American company wishing to provide its employees with shares as part of a bonus plan or a profit sharing scheme, or to acquire other

\footnotetext{
${ }^{21}$ A Ramaiya, 'Guide to the Companies Act', Part-I, Wadhwa Nagpur, 2006, p 938.

${ }^{22}$ Shashi Bala v. CIT, (1964) 34 Com Cases 985 (Guj).

${ }^{23}$ The Companies (Transfer of Profits to Reserves) Rules, 1975.

24 http://www.takeovers.gov.au/content/Resources/other_resources/downloads/jenkins_committee.pdf, accessed on 12/12/13.
} 
companies, will often accumulate a sufficient number of its own shares by purchase in preference to issuing new shares and thereby unnecessarily increasing its issued share capital. As companies in the United States are generally free to reduce their share capital without the consent of the Court, this power for a company to buy its own shares also makes it possible to effect a selective reduction of capital, the shares of those members who wish to sell them being bought by the company and then cancelled: members of small companies wishing to retire are often bought out in this way.

\section{Conclusion}

A limited company should be expressly prohibited from reducing its capital and from purchasing its own shares save as provided in the national legislation and the procedure for the reduction of capital must be designed to protect both creditors and shareholders. It might be suggested, however, that it is not always possible for the Court to protect the interests of a section of shareholders or a creditors unfairly prejudiced by a reduction of capital and that provision might be made whereby the court could obtain an independent assessment of the justice of a reduction scheme.

It has been suggested that in some circumstances, for example, where the reduction consists simply of cancelling paid up share capital which is lost or is represented only by such intangible assets as goodwill, it should not be necessary to obtain the consent of the Court. It will lessen the unnecessary hardship in the procedure.

To sum up, we can say that the national legislation must be designed to ensure that a company with a share capital raises it and subsequently makes no return to its shareholders unless net assets are retained which equal or exceed the value of that capital. 